Jelka Piškuric

\title{
Katoliška Cerkev v dokumentih Arhiva Jugoslavije ${ }^{1}$ The Catholic Church in the documents of the Archi- ves of Yugoslavia
}

Povz̨etek: Prispevek predstavlja pogled na jugoslovanske odnose s Katoliško Cerkvijo s stališča uradnih dokumentov najvišjih jugoslovanskih organov, ohranjenih v Arhivu Jugoslavije. Gre za časovno obdobje od sredine petdesetih do sredine sedemdesetih let - od prekinitve odnosov med Jugoslavijo in Svetim sedežem do postopnega iskanja možnosti za dialog. Kljub začrtanim spremembam v odnosih je oblast v angažiranosti Cerkve v družbenem življenju še vedno videla nevarnost - predvsem pri delu z mladimi, izdajanju verskega tiska in opravljanju karitativne dejavnosti. Zato je do Cerkve v vseh obdobjih vodila dvojno politiko, med jugoslovansko duhovščino pa skušala zanetiti razkol. Oblast je v svojih dokumentih večjo pozornost namenjala duhovnikom in razmeram na Hrvaškem, medtem ko je v slovenskih duhovnikih večinoma videla zmerno linijo, čeprav jo je skrbelo tudi njihovo delo. Republiška oblast v Sloveniji je bila do Cerkve zelo omejevalna. Na Hrvaškem je bilo stanje drugačno - del duhovščine se je upiral precej izraziteje, kar je oblast zaznavala kot težavo, ki jo je v svojih dokumentih tudi bolj izpostavljala.

Ključne besede: Katoliška cerkev, Jugoslavija, Slovenija, Hrvaška, Sveti sedež, odnosi, 1952-1975, Arhiv Jugoslavije, Kabinet predsednika republike, Komisija za verska vprašanja

Abstract: The paper presents a view at Yugoslav relations with the Catholic Church from the standpoint of official documents of the highest Yugoslav authorities, which are kept in the Archives of Yugoslavia. They present the period from the mid-1950s to the mid-1970s, from the suspension of diplomatic relations between Yugoslavia and the Holy See to the gradual search for opportunities for dialogue. In spite of the marked changes in relations, the authorities still saw danger in the Church's engagement in social life, especially when working with young people, publishing religious press and performing charitable activities.

1 Prispevek je nastal kot rezultat dejavnosti v okviru raziskovalnega programa P6-0380 „Zgodovinsko-pravni vidiki kršitev človekovih pravic in temeljnih svoboščin na slovenskem ozemlju v 20. stoletju do sprejetja ustave", ki ga sofinancira Javna agencija za raziskovalno dejavnost Republike Slovenije. 
That is why they pursued a dual policy towards the Church at all times and tried to provoke a schism among the Yugoslav clergy. The authorities paid more attention to clergy and the situation in Croatia in their documents, while in Slovene priests they saw mostly a moderate line, although they also saw reasons for concern in their work. The Slovene republican authorities were very restrictive towards the Church. In Croatia, the situation was different, some of the clergy also resisted much strongly, which the authorities perceived as a problem, and emphasized it in their documents.

Key words: Catholic Church, Yugoslavia, Slovenia, Croatia, Holy See, relations, 19521975, the archives of Yugoslavia, Office of the President of the Republic, Office for Religious Affairs

\section{Uvod}

Prispevek predstavlja pogled na odnose s Katoliško Cerkvijo (dalje: Cerkev) s stališča uradnih dokumentov najvišjih jugoslovanskih organov, ki jih najdemo v Arhivu Jugoslavije. Gre za dokumente od sredine petdesetih let, torej po jugoslovanski prekinitvi diplomatskih odnosov s Svetim sedežem, pa do sredine sedemdesetih let, ko so bili diplomatski odnosi že vzpostavljeni. Ob prekinitvi diplomatskih odnosov je Jugoslavija v Svetem sedežu videla glavno oviro pri urejanju odnosov med državo in Cerkvijo, kar se odraža tudi v dokumentih. $V$ tem obdobju si je namreč Jugoslavija pri urejanju odnosov z verskimi skupnostmi vzela pravico, da na temelju ustave njihovo delovanje uredi s posebnim zakonom. Pri tem je ureditev medsebojnih odnosov s Cerkvijo skušala doseči z neposrednimi pogajanji z jugoslovanskim episkopatom - in to mimo Svetega sedeža (Pacek 2016, 362-363). Ob poskusih za ponovno vzpostavitev diplomatskih odnosov se je stališče Jugoslavije do Svetega sedeža vsaj navidezno nekoliko spreminjalo, a ideološki odnos do vere je ostajal isti.

V Arhivu Jugoslavije sta zanimiva predvsem dva fonda: Zvezna komisija za verska vprašanja in Kabinet predsednika republike. Fond Zvezne komisije za verska vprašanja obsega nekaj manj kot 200 fasciklov. Gre za gradivo, ki povzema stanje po republikah oziroma stališča republiških komisij za verska vprašanja. Največ gradiva je o srbski pravoslavni cerkvi, ki je v Jugoslaviji imela tudi največ vernikov. Temu sledijo odnosi s Cerkvijo, pri čemer prednjačijo razmere na Hrvaškem, in odnosi s Svetim sedežem. Pri tem je veliko gradiva posvečenega organizaciji in delu duhovniških društev. Nekaj gradiva se nanaša tudi na druge verske skupnosti. Skoraj v vsakem fasciklu tega fonda se najde kakšen dokument, ki se nanaša na razmere v Sloveniji - v primerjavi z ostalimi republikami pa tega gradiva ni veliko. Največ dokumentov je o delovanju Cirilmetodijskega društva. Drugi zanimiv fond je fond Kabineta predsednika republike, ki vsebuje gradivo, ki ga je med letoma 1953 in 1980 prejemal ali pošiljal Titov kabinet. Razdeljen je na različne podfonde: zunanjepolitična vprašanja, družbeno-politična vprašanja, ekonomska politika, tisk, protokol, splošni posli, finančno-samoupravni posli in samoupravni organi. 
Fond ni organiziran po fasciklih, temveč po dokumentih in je zelo dobro popisan. Najbolj zanimiv je drugi podfond (družbeno-politična vprašanja), kjer se najdejo različni dokumenti o izseljencih in o odnosu do Cerkve ali o podobi Jugoslavije v tujem tisku. $V$ fondu so informacije odbrane za namen tega urada - večinoma gre za poročila o odnosih s Cerkvijo ali pa ustrezno izbrana pisma Titu, ki se zahvaljujejo ljudski oblasti in pozdravljajo delo, ki so ga opravljala duhovniška društva.

Glede na pregledano gradivo je mogoče reči, da to vsebuje predvsem splošen pregled odnosa Jugoslavije do različnih verskih skupnosti. Gotovo se bolj specifični in obsežnejši dokumenti lahko najdejo v posameznih arhivih nekdanjih jugoslovanskih republik. ${ }^{2}$ Vseeno pa je gradivo Arhiva Jugoslavije zanimivo, saj predstavlja, kaj je bilo s stališča republiških in zveznih oblasti najbolj pomembno, kaj je to sito prešlo in potovalo z lokalnega nivoja v Beograd. $V$ tem smislu so bili izbrani tudi dokumenti, na katere se opira prispevek - prikazujejo glavne prvine odnosa jugoslovanskih oblasti do Cerkve, ki je seveda izviral iz razumevanja vloge Cerkve v družbi in njenega omejevanja, budno spremljanje delovanja Cerkve, a tudi prve znanilce rahljanja skrajno napetih odnosov. Odnos slovenskih oblasti do Cerkve oziroma posamezni vidiki položaja Cerkve v Sloveniji po letu 1945 so bili v slovenskem zgodovinopisju že temeljito obdelani - predvsem na podlagi domačih virov (Gabrič 2003; 2016; Griesser Pečar 2005; 2013; 2017; Kurnjek, Maučec in Mozetič 1999; Mikola 2003; Pacek 2016; 2018; 2019; Režek 1999; 2002; Ščavničar 2012).

\section{Državne analize stanja v Cerkvi}

Po koncu druge svetovne vojne je bil odnos komunistične oblasti do Cerkve izrazito negativen, tako iz ideoloških kot iz političnih razlogov. $V$ njej je namreč videla ostrega nasprotnika svoje ideologije in močno ustanovo, ki je imela velik vpliv na kulturno in duhovno življenje ljudi. Napete odnose je poglobila tudi dejavnost Cerkve med drugo svetovno vojno, saj ji je oblast očitala sodelovanje z okupatorjem, ${ }^{3}$ ter nepopustljivost Svetega sedeža in papeža Pija XII. do nove družbene ureditve v Jugoslaviji (Režek 1999, 367-368). Komunistična oblast je Cerkev videla kot sovražen element, ki bi jo s svojo močjo, organizacijo in povezanostjo z ljudstvom utegnil ogroziti. Zato jo je bilo treba oslabiti, tako materialno kot politično, in omejiti njen vpliv na vernike, predvsem na mladino. Oblast je proti Cerkvi takoj ostro nastopila s sodnimi procesi, razlastitvami premoženja, omejevanjem katoliškega tiska, omejevanjem pastoralne dejavnosti in nadzorom nad duhovniki preko duhovniških društev (Griesser Pečar 2005, 87-103; Režek 1999, 370; Gabrič 2016, 316-318).

Čeprav je v začetku petdesetih let najhujši pritisk na politične nasprotnike postopoma ponehal, oblast v odnosu do Cerkve svojih stališč ni omilila, ampak

\footnotetext{
Za konkreten odnos oblasti do pastoralne dejavnosti Cerkve na Slovenskem, ki temelji na arhivskih dokumentih slovenske komisije za verska vprašanja, gl. dva obsežna prispevka Dejana Packa v Bogoslovnem vestniku (2018, 745-766; 2019, 153-179).

3 Še $v$ začetku petdesetih let $v$ gradivu najdemo opise posameznih katoliških organizacij in njihovih medvojnih aktivnosti (AJ 144, fasc. 5, a. e. 98, Marijine kongregacije, 4-7).
} 
celo zaostrila. Dno je bilo doseženo leta 1952, ko je Jugoslavija diplomatske odnose s Svetim sedežem prekinila. Povod za to je bilo imenovanje zagrebškega nadškofa Alojzija Stepinca ${ }^{4}$ za kardinala, toda vzroki so bili globlji - nepopustljivost Svetega sedeža ob kršitvah verske svobode, vprašanjih verskega izobraževanja in tiska ter prepovedi duhovniških društev. Še dodatno so bili odnosi napeti zaradi Svobodnega tržaškega ozemlja (Režek 2002, 309-314; Režek 1999, 369-383). Po prekinitvi diplomatskih odnosov se je Jugoslavija odločila odnose s Cerkvijo urediti mimo Svetega sedeža. Leta 1953 je bil sprejet Zakon o pravnem položaju verskih skupnosti, ki naj bi sicer zagotavljal svobodo vesti in veroizpovedi, a je med drugim izpovedovanje vere označil kot osebno stvar, poudaril načelo ločitve šole od Cerkve in omejil verski pouk. Po tem so pogovori med Cerkvijo in oblastjo zamrli za več let in večina cerkvenih dostojanstvenikov je odklanjala stik z državnimi organi v smislu tihega upora. Do sredine petdesetih let so odnosi med Cerkvijo in državo ostajali izrazito konfliktni, v drugi polovici desetletja pa se je ostrina manjšala iz leta v leto, kar se je kazalo tudi v izpuščanju obsojenih duhovnikov (Režek 2002, 315-316; Griesser Pečar 2012, 135-36; Režek 1999, 388).

Državni organi so stanje $v$ Cerkvi redno analizirali in analize pošiljali v kabinet predsednika. Iz poročil vidimo, da so oblast najbolj zanimali verske izobraževalne ustanove in njihov vpliv na mlade, katoliški tisk ter gmotno stanje Cerkve. Pred vojno, leta 1939, sta bili v Jugoslaviji dve teološki fakulteti, 14 višjih teoloških šol, 32 srednjih verskih šol in 20 noviciatov s skupno 2827 slušatelji. Eno od poročil navaja, da je imela obravnavana verska skupnost kljub zakonskim omejitvam in administrativnim ukrepom ob koncu petdesetih let največ verskih šol, in sicer 2 teološki fakulteti, 6 teoloških visokih šol, 11 verskih srednjih šol in 12 noviciatov, ki jih je skupaj obiskovalo okoli 1800 slušateljev. Po jugoslovanski zakonodaji Cerkev seveda ni več mogla imeti splošnih klasičnih gimnazij (AJ 144, fasc. 23, a. e. 250, Izveštaj za 1957 godinu, 17-18). Šolstvo je bilo namreč za uveljavljanje komunistične ideologije ključno in kmalu po koncu vojne je oblast izdala prepoved delovanja verskih srednjih šol. V Sloveniji je republiška oblast prepoved izvedla dosledno in ukinjeni so bili vsi katoliški vzgojni zavodi. Podržavljeno je bilo premoženje internatov in drugih zavodov za dijake in študente. Le Teološka fakulteta je še za nekaj časa obstala, a bila kljub temu deležna pritiskov oblasti - dokler je leta 1952 niso iz Univerze v Ljubljani izločili. Drugače kot v Sloveniji je na Hrvaškem veliko zasebnih verskih vzgojnih zavodov s svojim delovanjem nadaljevalo - to je bilo dobrodošlo tudi za dijake iz Slovenije, ki so se lahko preusmerili tja (Gabrič 2009, 153-161). Verski pouk za otroke in mladino je oblast budno spremljala tudi $v$ naslednjih letih - po njenih podatkih naj bil bilo v Sloveniji v začetku šestdesetih let v versko vzgojo vključenih od 60 do 100 odstotkov mladine na podeželju in od 5 do 30 odstotkov v mestih. Na Hrvaškem je bil odstotek mladine, ki je bila vključena v versko vzgojo v mestih, precej večji (AJ 837, šk. II-10, Informacija, 22. 6. 1964, 7-8).

4 Alojzije Viktor Stepinac (1898-1960), hrvaški nadškof, kardinal, mučenec in blaženi, je imel pomembno vlogo v jugoslovanskem cerkvenem vrhu in v odnosih Jugoslavije s Svetim sedežem v celotnem obdobju od konca vojne do svoje smrti (Režek 1999, 368). 
Drugi kamen spotike je bil za oblast katoliški tisk. Pred drugo svetovno vojno je Cerkev izdajala večje število časopisov, glasil in drugih edicij, po vojni pa je bil verski tisk močno omejen. Tudi tu je do nekaterih sprememb prišlo v času zaostritve odnosov med Cerkvijo in oblastjo leta 1952. V Sloveniji sta bila na primer v tem času ukinjena verska lista ljubljanske in mariborske škofije, dovoljenje za izdajanje novega glasila Družina pa je dobila apostolska administratura v Novi Gorici. Ker je bilo to edino versko glasilo, so se njegovi bralci kmalu razširili na celotno Slovenijo (Gabrič 2009, 158). Ob koncu petdesetih let je Cerkev v Jugoslaviji izdajala le glasila Blagovest (mesečnik beograjske nadškofije), Vjesnik (mesečnik đakovske škofije), Družino (mesečnik apostolske administrature v Novi Gorici), Vjesnik (tromesečnik združenja katoliških duhovnikov na Hrvaškem), Dobrega pastirja (mesečnik istoimenskega združenja katoliških duhovnikov v Bosni in Hercegovini) ter Organizacijski vestnik in Novo pot (mesečnik oziroma tromesečnik Cirilmetodijskega društva v Sloveniji). Poleg navedenega je izdajala še različne knjige za bogoslužje, učbenike in koledarje (AJ 144, fasc. 23, a. e. 250, Izveštaj za 1957 godinu, 19). V začetku šestdesetih let se je dejavnost izdajanja knjig in revij v duhu splošnih sprememb nekoliko povečala. Tako naj bi samo na Hrvaškem izdajali 11 različnih časopisov oziroma glasil ter natisnili okoli 150 različnih knjig in brošur (AJ 837, šk. II-10, Informacija, 22. 6. 1964, 7).

Čeprav je Cerkev z različnimi ukrepi - predvsem z agrarno reformo - izgubila veliko svojih posesti, so oblast njeni dohodki še vedno skrbeli. Cerkev je bila v Sloveniji med razlaščenimi lastniki sicer na prvem mestu - največ posesti so izgubili ljubljanska in mariborska škofija ter posamezni redovi oziroma njihovi samostani in ustanove. Posesti so izgubile tudi župnije, s čimer jim je bilo odvzeto materialno zaledje za vzdrževanje ${ }^{5}$ (Čepič 2005, 886; Ščavničar 2012, 147-148). Cerkev je imela po podatkih državnih organov ob koncu petdesetih let 5364 cerkvenih objektov - mednje so šteli cerkve, kapele in samostane. Pri tem so poudarjali, da naj bi bilo med vojno porušenih le okoli 171 cerkev, po vojni pa zgrajenih 353. Oblast je menila, da je bil tudi po uveljavitvi zakona o agrarni reformi dohodek iz nepremičnin in zemlje za Cerkev še vedno pomemben vir. Temu so sledili dohodki iz darov in dohodki iz tujine, kar so ocenjevali na 70 milijonov dinarjev letno. Niso pa pozabili niti na individualne pakete tekstila in hrane ali dotacije, ki so bile namenjene duhovniškim društvom (AJ 144, fasc. 23, a. e. 250, Izveštaj za 1957 godinu, 17-20). Analiza iz leta 1964 ugotavlja, da je imela Cerkev 5569 cerkva in 364 samostanov. Po vojni naj bi bilo po takratnih podatkih obnovljenih 1574 objektov in še 31 zgrajenih (AJ 837, šk. II-10, Informacija, 22. 6. 1964, 7).

\section{Petdeseta leta v luči uradnih dokumentov}

Tudi v stanju zamrznjenih odnosov je oblast skušala Cerkev nadzorovati, škofe in duhovnike pa razcepiti s pomočjo duhovniških društev. Ta so bila dejansko glavno

Obenem je oblast na duhovnike izvajala ekonomski pritisk z visoko obdavčitvijo (Griesser Pečar 2013, 355; AJ 144, fasc. 6, a. e. 106, Pitanje oporezivanja klera, 26. 12. 1952). 
sredstvo za usmerjanje odnosov s Cerkvijo v želeno smer oziroma za razkrajanje Cerkve in njene notranje hierarhije (Režek 1999, 377). Oblasti so v njihovem delovanju videle možnost odvračanja duhovnikov od Svetega sedeža s tem, da so članom nudile reševanje nekaterih vprašanj: pridobivanje dovoljenj za poučevanje verouka ali potovanja, večjo svobodo pri opravljanju verskih obredov, olajšave pri plačevanju davkov, materialno pomoč ter dovoljenja za obnovo cerkva in župnišč, možnost kupovanja v posebnih zadrugah, založniško dejavnost, tudi skrb za socialno in zdravstveno zavarovanje (AJ 144, fasc. 6, a. e. 110, Opravljeno delo; Griesser Pečar 2017, 431).

Cirilmetodijsko društvo katoliških duhovnikov, ki je bilo ustanovljeno leta 1949 v Sloveniji, je bilo prvo stanovsko društvo duhovnikov v Jugoslaviji. Kmalu za njim je bilo ustanovljeno duhovniško društvo $v$ Bosni in Hercegovini in šele nekaj let kasneje v Srbiji ter na Hrvaškem. ${ }^{6}$ Da bi preprečili zaostrovanje, slovenski škofje namenoma niso objavili prepovedi duhovniških društev, ki jo je leta 1950 izdal Sveti sedež (Dolinar 1998, 226). Oblast pa je v tem videla svoj uspeh: menila je, da je Cirilmetodijsko društvo najbolj aktivno tako pri izdajanju glasila kot pri reševanju stanovskih vprašanj. V njem naj bi se zbrali tisti duhovniki, ki so svoje ,patriotsko' stališče pokazali že med vojno (AJ 144, fasc. 23, a. e. 276, Pregled rada, 21. 9. 1957, 1-2; Griesser Pečar 2017, 423-429). Dokumenti so delo duhovniških društev seveda predstavljali le v pozitivni luči - duhovniki člani da so »na terenu med narodom in lahko zelo uspešno delujejo $v$ smeri verske tolerance raznih veroizpovedi, $v$ smeri krepitve državne in narodne enotnosti, predvsem pa v negovanju in čuvanju dosežkov narodnoosvobodilnega boja« (AJ 144, fasc. 23, a. e. 276, Pregled rada, 21. 9. 1957, 3).

Sredi petdesetih let so se v odnosih začele kazati prve spremembe. Leta 1954 je bil za zagrebškega nadškofa koadjutorja imenovan Franjo Šeper, ${ }^{7}$ za katerega je oblast zapisala, da je človek, ki se bo izogibal skrajnostim in si prizadeval iskati možnosti za sožitje. $V$ njegovem imenovanju je tako videla namero Svetega sedeža, da bo odnose med Cerkvijo in Jugoslavijo urejal z večjo zadržanostjo kot prej. Zato je bilo izdano navodilo, da morajo tudi državni organi spodbujati mirnejše reševanje sporov in odnosov do predstavnikov Cerkve ne smejo zaostrovati (AJ 837, šk. II-10, Informacija, 15. 11. 1955, 1). Oblast je ocenjevala, da obstajata dve skupini duhovnikov. K skupini prvih, ,bolj umirjenih', je prištevala beograjskega nadškofa Josipa Ujčića, ${ }^{8}$ zagrebškega nadškofa koadjutorja Šeperja, ljubljanskega

6 Duhovniško društvo Dobri pastir v Bosni in Hercegovini je bilo ustanovljeno leta 1950. Poskusi ustanovitve duhovniškega društva na Hrvaškem so sprožili velik odpor, zato je bilo ustanovljeno šele leta 1953. Vanj je bila vključena manj kot desetina duhovnikov. Istega leta sta bili ustanovljeni tudi duhovniški društvi v Srbiji in Črni gori (Režek 2005, 953; Griesser Pečar 2017, 425).

7 Franjo Šeper (1905-1981), hrvaški duhovnik, zagrebški nadškof koadjutor, od leta 1960 zagrebški nadškof, leta 1965 povzdignjen v kardinala in leta 1968 imenovan za prefekta Kongregacije za doktrino vere.

8 Josip Ujčić (1880-1964), srbski duhovnik, od leta 1936 beograjski nadškof in banatski apostolski administrator, med letoma 1948 in 1961 predsednik škofovske konference Jugoslavije. 
škofa Antona Vovka, ${ }^{9}$ mariborskega škofa Maksimilijana Držečnika, ${ }^{10}$ đakovskega škofa Antuna Akšamovića, ${ }^{11}$ barskega nadškofa in srbskega primasa Nikolo Dobrečića ${ }^{12}$ ter zagrebškega pomožnega škofa Josipa Lacha. ${ }^{13} \mathrm{Na}$ drugi strani je videla ,najbolj reakcionarne' škofe, kot jih je poimenovala sama. To so bili splitski škof Frane Franić, ${ }^{14}$ šibeniški škof Ćiril Banić, ${ }^{15}$ zadrski škof Mate Garković, ${ }^{16}$ reški škof Josip Pavlišić, ${ }^{17}$ krški škof Josip Srebrnič ${ }^{18}$ in skopski škof Smiljan Franjo Čekada. ${ }^{19}$ Umirjenost prvih je videla $v$ tem, da so se nanjo obračali v reševanju nekaterih konkretnih vprašanj (predvsem pomilostitev), in v zmernejšem odnosu do članov duhovniških društev. $V$ svojih poročilih je oblast izpostavljala tudi nasprotovanja med zmernejšimi in radikalnimi škofi, pri tem pa kot nosilca zmernejše linije navajala ljubljanskega in mariborskega škofa (AJ 837, šk. II-10, Informacija, 15. 11. $1955,2-7)$. Taka nasprotovanja so oblasti samo koristila oziroma jih je še bolj poudarjala, da je izpostavila pravilnost svojih stališč in delovanja duhovniških društev, saj najdemo celo zapise kot: „Ni dvoma, da je opisana politika odnosa do te cerkve in njeno praktično izvajanje s strani zvezne in republiških verskih komisij prinesla pozitivne rezultate, in prav razlikovanje, ki je nastalo znotraj cerkve, kaže, da je treba s tako linijo nadaljevati, ker v osnovi obstajajo možnosti, da se na ta način najbolje rešujejo odnosi te cerkve do države.« (AJ 837, šk. II-10, Informacija, 15. 11. 1955,9$)$

Jugoslavija je pozorno spremljala novice tujih časopisov in v njih pogosto videla ,vatikansko propagando' proti sebi. Vsebina teh novic je bila raznolika, značilno pa je, da je oblast v njih zaznavala poskus oslabitve položaja Jugoslavije v medna-

9 Anton Vovk (1900-1963), slovenski duhovnik, kot generalni vikar junija 1945 prevzel vodstvo ljubljanske škofije, leta 1950 imenovan za apostolskega administratorja ljubljanske škofije, po smrti škofa Gregorija Rožmana leta 1959 pa za ljubljanskega škofa in leta 1960 za nadškofa.

10 Maksimilijan Držečnik (1903-1978), slovenski duhovnik, septembra 1946 imenovan za pomožnega škofa v Mariboru, po smrti škofa Ivana Jožefa Tomažiča leta 1949 imenovan za apostolskega administratorja lavantinske škofije, leta 1960 pa za rednega škofa.

11 Antun Akšamović (1875-1959), hrvaški duhovnik, leta 1920 imenovan za đakovskega škofa, leta 1942 razrešen s tega položaja in imenovan za apostolskega administratorja đakovske in sremske škofije.

12 Nikola Dobrečić (1872-1955), srbski duhovnik, po rodu iz Črne gore, od leta 1912 barski nadškof in srbski primas.

13 Josip Lach (1899-1983), hrvaški duhovnik, pomožni zagrebški škof, generalni vikar v času nadškofa Stepinca in kasneje kardinalov Šeperja in Franja Kuharića.

14 Frane Franić (1912-2007), hrvaški duhovnik, od leta 1954 splitsko-makarski škof, od leta 1969 nadškof.

15 Ćiril Banić (1890-1961), hrvaški duhovnik, od leta 1951 apostolski administrator v Šibeniku, od leta 1960 škof Šibenika.

16 Mate Garković (1882-1968), hrvaški duhovnik, leta 1950 imenovan za apostolskega administratorja zadrske nadškofije, leta 1961 za zadrskega nadškofa.

17 Josip Pavlišić (1914-2005), hrvaški duhovnik, leta 1951 imenovan za senjsko-modruškega škofa, leta 1969 za reško-senjskega škofa koadjutorja in leta 1974 za nadškofa.

18 Josip Srebrnič (1876-1966), slovenski duhovnik, leta 1923 imenovan za škofa na Krku, leta 1963 dobil častni naslov nadškofa ob štiridesetletnici škofovstva.

19 Smiljan Franjo Čekada (1902-1976), bosanski duhovnik, leta 1939 imenovan za vrhbosanskega pomožnega škofa, leta 1940 za skopsko-prizrenskega škofa, med letoma 1946 in 1949 začasno upravljal banjaluško škofijo, za vrhbosanskega nadškofa koadjutorja imenovan leta 1967, za nadškofa leta 1970. 
rodni politiki. Iz poročil vidimo, da so bili v tujini o dogajanju v Jugoslaviji zelo dobro obveščeni. Oblast je seveda vse vesti iz tujine skušala zavreči z obširnimi razlagami svojega pogleda na Cerkev in njeno dejavnost. Največ prispevkov, ki jih je spremljala, je bilo posvečenih odnosu med državo in Cerkvijo ter svobodi veroizpovedi. Očitki so leteli zlasti na Radio Vatikan, ki mu je oblast očitala izpostavljanje sodnega preganjanja katoliških duhovnikov - še posebej ob odmevnejših pomilostitvah - ter zavračanje duhovniških društev. O preganjanju katoliških duhovnikov in kaznovalni politiki so pisale tudi druge agencije in časopisi po Evropi, ki jim je Jugoslavija seveda očitala netočnost in neresničnost. Najbolj jo je motilo, da so izpostavljali trpljenje duhovnikov ob krivičnih obsodbah in mučnem prestajanju kazni. Prav tako so bila predmet člankov iz tujine duhovniška društva in poskusi Jugoslavije, da bi z njimi nadzirala delovanje duhovnikov in jih odmaknila od Svetega sedeža (AJ 144, fasc. 19, a. e. 237, Vatikanska propaganda, 3. 4. 1956, 1-4). Tako v tujem tisku kot v jugoslovanskih odnosih s Svetim sedežem je ostajal sporen tudi kardinal Stepinac, ki je bil po prestani zaporni kazni leta 1951 obsojen na hišni pripor v rojstnem Krašiću, kjer je ostal do smrti leta 1960 (AJ 144, fasc. 19, a. e. 237, Vatikanska propaganda, 3. 4. 1956, 6-7). Posamezne vesti iz tujine so opisovale še omejevanje svobode veroizpovedi, poskuse oblasti odvračati mladino od verskega življenja, pritisk na verske šole, težke gmotne razmere duhovnikov, povezane $z$ visokimi dajatvami in drugimi administrativnimi ukrepi, ukinitev katoliškega tiska. Oblast je motilo tudi to, da sta bila predmet novic slabo ekonomsko stanje in pomanjkanje $v$ državi ter normalizacija odnosov s Sovjetsko zvezo leta 1955 (AJ 144, fasc. 19, a. e. 237, Vatikanska propaganda, 3. 4. 1956, 7-14). Ozadje intenzivnega spremljanja tujih novic je bila ponovna zaostritev politike oblasti do Cerkve leta 1956, do katere je prišlo predvsem zaradi pastirskega pisma papeža Pija XII., ki je katoličane pozval, naj zdržijo pritisk komunističnih oblasti, nekoliko pa tudi zaradi strahu, ki ga je sprožila vstaja na Poljskem - v njej so imeli pomemben vpliv tudi cerkveni dostojanstveniki. V Jugoslaviji so pritisk oblasti na Cerkev takrat najbolj občutili na Hrvaškem (Režek 2002, 317).

Oblast je tudi v drugi polovici petdesetih let Cerkev pozorno spremljala in v strogo zaupnem dokumentu zapisala, da odnosi še niso normalizirani, da pa naj bi vseeno prišlo do prevlade umirjene struje. To naj bi se po njenem mnenju kazalo v zadržanosti Cerkve in Svetega sedeža do države. „Nedvomno je, da se je bil episkopat primoran zavedati dejstva, da spremembe v našem družbenem sistemu nimajo prehodnega značaja, " so zapisali in dodali, da je tudi stališče oblastnih organov in družbenopolitičnih organizacij »nadzorovano umirjeno», kar se izraža v zmanjšanju števila kaznovanih duhovnikov in odsotnosti grobih javnih napadov na duhovnike (AJ 144, fasc. 23, a. e. 250, Izveštaj za 1957 godinu, 20-21). Čeprav je bila zaznana zadržanost cerkvenih dostojanstvenikov dejansko njihov tihi upor, je oblast v njej videla uspeh svoje politike sekularizacije družbe. Možnost za razburkanje tega prisilno mirnega stanja je videla v škofih, ki so do države in do duhovniških društev izražali ostrejša stališča. Oblast je bila celo mnenja, da so duhovniška društva v stagnaciji - škofje v Sloveniji, Bosni in Hercegovini, Črni gori in Srbiji naj bi jih tolerirali, medtem ko so bile na Hrvaškem razmere do društva 
in njegovih članov bolj ostre, zaradi česar naj bi bilo društvo v ,boju za obstanek'. Tudi odnosi državnih organov do Cerkve po republikah niso bili enaki. Najboljši naj bi bili v Sloveniji, kjer naj bi bili kontakti s škofoma in duhovniki stalni. V drugih republikah pa teh stikov praktično ni bilo - samo z duhovniškimi društvi. Pri tem so ocenili, da so najtežje razmere na Hrvaškem, »kjer se nahaja največji del episkopata in sedež škofovske konference, najmočnejša ustaška tradicija, pa tudi vpliv Stepinca (AJ 144, fasc. 23, a. e. 250, Izveštaj za 1957 godinu, 24-25). Dejansko je republiška oblast v Sloveniji striktno uvajala ločitev Cerkve in države ter delo duhovnikov in redovnikov nadzorovala in omejevala (Griesser Pečar 2013, 354360). Na Hrvaškem so bile razmere drugačne, del duhovščine pa je proti oblasti vodil izrazit upor. Zato je zvezna oblast največjo težavo prepoznavala v hrvaški duhovščini in emigraciji - in jo v svojih dokumentih najbolj izpostavljala.

Oblast je težavo videla tudi v pastoralni dejavnosti, predvsem v vplivu vere na mladino, kar je skušala omejiti - a ne vedno uspešno, saj je bil ponekod zaznan celo porast števila vernikov. Zato se je pritoževala, da duhovščina uporablja vedno nove metode, s katerimi bi poživila versko življenje. Izpostavljala je na primer duhovne obnove, poskuse za povečanje obiska pri verouku (tako s filmi kot z izpostavljanjem otrok, ki k verouku ne hodijo, in njihovih staršev), povečanje števila vernikov (ki so ga pripisali relativno pasivnemu stališču družbenopolitičnih organizacij v določenih okrajih), izostanek otrok v šolah zaradi verskih obveznosti, povečanje cerkvenih porok in krstov, množičnejšo udeležbo pri polnočnicah, pa tudi verske aktivnosti določenega dela članov zveze komunistov in učiteljev. To je poudarjala predvsem za nekatere dele Hrvaške ter Bosne in Hercegovine. Oblasti je skrbelo še, da bi Cerkev lahko izboljšala svoje materialno stanje, ki ga je Jugoslavija zakonsko omejila (AJ 144, fasc. 23, a. e. 250, Izveštaj za 1957 godinu, 27-30).

Zaradi vsega tega je oblast svoje načelo ločitve države od Cerkve dosledno izvajala. Pri tem je pogosto spoštovala predvsem tiste zakonske določbe, ki so verske skupnosti omejevale, tistih o njihovih pravicah pa ne (Režek 2002, 316). Stališče najvišjih državnih organov je bilo, da so verske skupnosti - kljub upiranju nekaterih posameznikov - v spremenjenih pogojih nove družbene ureditve ,sprevidele', da morajo, če želijo razvijati svoje delovanje, z državo vzdrževati normalne odnose. Priporočilo Zveznega izvršnega sveta predsednikom republiških izvršnih svetov, ki ga je podpisal Aleksandar Ranković, ${ }^{20}$ opisuje odnose s pravoslavno, islamsko, starokatoliško in judovsko versko skupnostjo ter z večino protestantskih verskih skupnosti kot večinoma normalne. ${ }^{21}$ Za katoliško Cerkev pa pravi, da so se odnosi nekoliko izboljšali, a da še niso taki, da bi jih imeli za normalne, saj naj ta verska skupnost ne bi želela uskladiti svojega delovanja z obstoječo zakonoda-

20 Aleksandar Ranković (1909-1983), eden najvplivnejših jugoslovanskih politikov do sredine šestdesetih let, podpredsednik vlade oziroma izvršnega sveta, prvi mož Udbe in Titova desna roka. Leta 1966 so ga z obtožbo, da je izrabil Udbo za vohunjenje proti političnim nasprotnikom, odstranili z vseh položajev.

21 Dejansko so tudi v odnosih teh verskih skupnostih z državo obstajale napetosti in odprta vprašanja, a oblast je nasprotovanje politični ureditvi v Jugoslaviji pripisovala zlasti delu katoliških duhovnikov. Po številu vernikov je bila Cerkev na drugem mestu in oblast je $v$ tem videla potencialen vpliv na lojalnost državljanov (AJ 837, šk. II-10, Informacija, 22. 6. 1964, 1-10; AJ 837, šk. II-10, Neka pitanja, 31. 10. 1968, 1-15). 
jo. Oblast se je zavedala, da so odnosi med Cerkvijo in državo kompleksni in občutljivi, zato naj bi jim organi in politične organizacije posvečali popolno pozornost, da bi dosegli »bolj učinkovite rezultate $v$ razvijanju pozitivnih usmeritev $v$ cerkvenih vrstah « (AJ 837, II-10, Pretsedniku izvršnog veća, 18. 7. 1959, 3-4). Oblast se je pri tem bala tistih posameznikov, ki so imeli do nje izrazito negativno stališče, zato je izpostavljala njihovo politično stališče in pridobivanje materialne pomoči iz tujine (od politične emigracije). Svarila je tudi pred pretirano obdavčitvijo, ki bi lahko imela negativne posledice, in predlagala učinkovitejšo obnovo cerkva, da ne bi prihajalo do nezadovoljstva verskih skupnosti. Vedno jo je skrbela aktivnost Cerkve pri vzgoji mladine, zato je menila, da morajo politične in družbenopolitične organizacije - zlasti mladinska - spremljati aktivnosti pri poučevanju verouka in njegov vpliv na mladino: priporočala je, naj imajo krajevni in občinski organi nad stanjem na svojem terenu pregled. Velik pomen je oblast pripisovala nepretrganemu vzdrževanju stikov s predstavniki verskih skupnosti, s predstavniki duhovniških društev in z drugimi duhovniki. Pri tem je bil vedno izpostavljen pritisk, ki naj bi se na člane duhovniških društev izvajal, in poudarjena potreba, da se jim nudi podporo, da ne bi ostali izolirani (AJ 837, II-10, Pretsedniku izvršnog veća, 18. 7. 1959, 4-8).

Poročila so tudi še ob koncu desetletja izpostavljala razhajanje katoliških škofov $v$ taktiki do oblasti. Razhajanje naj bi se nanašalo predvsem na duhovniška društva in različna stališča do sporazumnega reševanja posameznih problemov. Prva skupina, v katero je oblast tokrat uvrstila Stepinca, Čekado, Franića, Stjepana Bäuerlaina, ${ }^{22}$ Banića in Srebrniča, naj bi bila proti vsakemu sodelovanju; druga skupina, v katero naj bi spadali Ujčić, Držečnik, Vovk, Gabrijel Bukatko, ${ }^{23}$ Lach, Gracija Ivanović ${ }^{24}$ in do neke mere tudi Šeper, naj bi se s stiki in pogovori trudila nekatera odprta vprašanja rešiti sporazumno (AJ 837, II-10, Odnosi izmedju države, 6. 10. 1959, 2). Oblast je bila še vedno pozorna na kritike cerkvenih dostojanstvenikov na račun družbenega sistema, morale, vzgoje mladine in sekularizacije družbe. Pri tem je zapisala, da je v letu 1959 niz dejstev kazal na to, „da realistične ideje umirjenih škofov pridobivajo vse več podpornikov $v$ vrstah višje in nižje duhovščine in da je vse večje število tistih, ki so za sodelovanje z oblastmi, pa tudi če v omejenem obsegu « (AJ 837, II-10, Odnosi izmedju države, 6. 10. 1959, 3). K temu naj bi po mnenju oblasti pripomogel tudi obisk zmernejših škofov pri Svetem sedežu. ${ }^{25}$

22 Stjepan Bäuerlein (1905-1973), hrvaški duhovnik, ki je leta 1959 nasledil Akšamovića kot đakovski in sremski škof.

23 Gabrijel Bukatko (1913-1981), grkokatoliški duhovnik, od leta 1950 apostolski administrator škofije v Križevcih, od leta 1960 tudi naslovni škof, po smrti Ujčića leta 1964 imenovan za beograjskega nadškofa.

24 Gracija Ivanović (1903-1983), črnogorski duhovnik, med letoma 1937-1938 (in nato ponovno 19501981) apostolski administrator kotorske škofije.

25 Oblasti so kot prvemu dovolile obisk pri Svetem sedežu Lachu jeseni 1957, v naslednjem letu sta mu sledila še Šeper in Ujčić (Režek 2002, 318). 


\section{Na poti k spremembam}

Ob koncu petdesetih let je postopoma le prišlo do prvih znakov, da je Jugoslavija odnos med državo in Cerkvijo pripravljena urejati. Na pripravljenost za obnovo dialoga je na eni strani pozitivno vplivala smrt papeža Pija XII., ki je komunizmu ostro nasprotoval, oktobra 1958 in nastop papeža Janeza XXIII., ki je bil poznan po svoji odprtosti, toplini, preprostosti in čutu za socialno pravičnost. Na drugi je na možnosti za dialog vplivalo odpiranje Jugoslavije navzven (na Zahod), prevzemanje vodilne vloge $v$ gibanju neuvrščenih ter zmerno popuščanje partijske netolerance do Cerkve in religije. Število kaznovanih duhovnikov v Sloveniji je začelo upadati, čeprav je tako v Sloveniji kot na Hrvaškem še v začetku šestdesetih let potekalo več sodnih procesov. ${ }^{26}$ Ko je februarja 1960 umrl in bil v zagrebški stolnici pokopan kardinal Stepinac, ni bilo več še zadnje velike ovire za umiritev odnosov. Jeseni tega leta so željo po obnovitvi dialoga z memorandumom podprli tudi jugoslovanski škofje ob koncu redne letne konference. Umirjanje jugoslovanske strani se je v prvi polovici šestdesetih let kazalo v popuščanju pritiska na Cerkev: oblast verskih obredov ni več ovirala v taki meri, manjšale so se ovire za obnovo in gradnjo cerkva ter za izdajanje verskega tiska (Režek 2002, 318-320; Pacek 2016, 365-367).

V uradnih dokumentih je oblast izboljšanje odnosov $v$ začetku šestdesetih let še vedno pripisovala duhovniškim društvom in tistemu delu duhovščine, ki je imel do nje bolj umirjen odnos, težave pa je videla $v$,ekstremnem delu' duhovščine, v pritiskih na duhovniška društva, zlasti na Hrvaškem, in v vplivih iz emigracije (AJ 837, II-10, Informacija, 22. 6. 1964, 5-8). Odnose s Cerkvijo je še vedno želela urediti z domačimi škofi, a se je morala kmalu sprijazniti, da se bo morala obrniti na Sveti sedež. K dialogu so prispevali sklepi drugega vatikanskega koncila - z dovoljenjem oblasti so se ga smeli udeležiti tudi jugoslovanski škofje. Papeža Janeza XXIII. je leta 1963 nasledil papež Pavel VI., ki je politiko predhodnika do komunističnih držav nadaljeval (Režek 2002, 320).

Jugoslavija in Sveti sedež sta stike najprej v tajnosti vzpostavila leta 1962 in šele sredi leta 1964 so se začela uradna pogajanja (Pacek 2016, 368; Režek 2002, 320). Od takrat lahko sledimo vladnim informacijam o medsebojnih odnosih in pogovorih. V dokumentu iz leta 1964 je oblast potrdila vzpostavitev neposrednih stikov med Svetim sedežem in jugoslovansko ambasado v Rimu. Jugoslavija je upala zlasti na vzpostavitev modusa vivendi med sabo in Cerkvijo oziroma Svetim sedežem, kar bi po njenem pri vzpostavljanju diplomatskih odnosov pomenilo korak naprej. Vztrajala pa je, da se pravni položaj Cerkve uredi v skladu z zakonodajo države. Sveti sedež je po drugi strani vztrajal pri priznavanju svoje suverenosti v verskih zadevah in pri svobodnem delovanju Cerkve na vseh področjih (AJ 837, šk. II-10, Informacija, 22. 6. 1964, 8; AJ 837, šk. II-10, Informacija, 20. 10. 1964; 2-4). V svojih dokumentih je oblast ugotavljala pripravljenost Svetega sedeža za iskanje sporazuma - videla je celo naglico in pripravljenost na prilagajanje. Težavo je zanjo

26 V Sloveniji je leta 1961potekal sodni proces proti 12 duhovnikom. 7 jih je bilo obsojenih na zaporno kazen in 5 na denarno. Do leta 1975 je bilo obsojenih še najmanj 137 duhovnikov, 105 na zaporno kazen, 22 na pogojno zaporno kazen in 10 na denarno (Griesser Pečar 2005, 104; Griesser Pečar 2013, 354-355). 
predstavljala zahteva po omogočanju delovanja Cerkve na vseh področjih družbenega življenja, predvsem pri vzgoji mladine. $V$ pogovorih je ostalo odprtih mnogo vprašanj: imenovanje škofov, delovanje duhovnikov v emigraciji, duhovniška društva, Zavod sv. Hieronima, ${ }^{27}$ kanonizacija bl. Nikole Tavelića in beatifikacija kardinala Stepinca, ${ }^{28}$ nevtralnost države in spoštovanje načela svobode, vesti in veroizpovedi, vzgoja mladine, verski prazniki ter verski pouk (AJ 837, šk. II-10, Informacija, 20. 10. 1964; 5-7).

Kot prej je tudi v tem času Cerkev in njena dejavnost ostajala v središču pozornost oblasti. Tako je bil na eni od sej organizacijsko-političnega sekretariata CK ZK Hrvaške glavni predmet razprave njeno prilagajanje sodobnim metodam delovanja. $V$ dejavnosti Cerkve niso videli toliko neposrednega nasprotovanja socializmu, kolikor pridobivanje večjega števila vernikov in širjenje religioznosti. Izpostavljali so vključevanje Cerkve v dejavnosti lokalnega okolja, povezovanje mladine s športnimi dejavnostmi, prikazovanje filmov, oblikovanje župnij v delavskih okoljih, pomlajevanje duhovščine, celo humanitarno dejavnost. $V$ vsem tem so videli širjenje njenega vpliva, pri čemer so se še vedno najbolj bali vpliva na mladino. Skrbelo jih je tudi, da Cerkev kritično spremlja družbene pojave v državi. Menili so, da idejni boj komunistov proti religiji ni dovolj organiziran in da v zvezi komunistov ni dovolj usposobljenih kadrov, ki bi se lahko takemu delovanju Cerkve uprli. Ugotovili so, da sicer pozitivno vplivajo šola, filmi, tisk, knjige, predavanja in druga sredstva informiranja, drugod pa je to prepuščeno stihiji (AJ 837, šk. II-10, Neke reperkusije, 26. 12. 1964, 1-4). V Sloveniji jih je zmotila velika udeležba na koncilskem misijonu in pa redefinicija vloge laikov v Cerkvi (AJ 837, šk. II-10, Savremene metode, 10. 5. 1966, 1-3).

Pogajanja med Jugoslavijo in Svetim sedežem so se nadaljevala leta 1965, najprej v Beogradu in ob koncu leta v Rimu. Jugoslavija je vztrajala, da morajo odnosi s Cerkvijo temeljiti na ustavi in drugih zakonskih podlagah; v odnosu do ostalih verskih skupnosti ni dovolila nobenih izjem (Pacek 2016, 369-372). Menila je, da Sveti sedež v pogajanjih išče predvsem možnosti širšega delovanja, kot je bilo to določeno $z$ zakonodajo, in da ideološka vzgoja mladine $v$ šolah ne vpliva na izražanje veroizpovedi ter versko vzgojo. Čeprav naj bi se v pogajanjih izkazalo, da v stališčih obstajajo bistvene razlike - Jugoslavija si je najbolj želela politične nevtralizacije duhovščine v emigraciji, zagotovila, da se Zavod sv. Hieronima ne bo izrabljal v politične namene, priznavanja duhovniških društev in pa upoštevanja državnega mnenja pri imenovanju škofov -, je oblast videla tudi obojestranski interes za ureditev razmer. Kot največji dosežek pa seveda dejstvo, da je moral Sveti sedež kot osnovo za urejanje odnosov sprejeti ustavo in Zakon o pravnem položaju verskih skupnosti - s čimer naj bi po mnenju oblasti priznal tudi družbeno ureditev (AJ 837, šk. II-10, Informacija, 27. 5. 1966, 1-3).

27 Zavod sv. Hieronima v Rimu je deloval od leta 1901. Po koncu druge svetovne vojne je postal središče hrvaške katoliške in politične emigracije. Za jugoslovansko stran je bil najbolj moteč njegov protikomunistični in protijugoslovanski vpliv (Pacek 2016, 369-370).

28 Nikola Tavelić (okoli 1340-1391), hrvaški frančiškan in mučenec iz 14. stoletja, je prvi uradno kanonizirani hrvaški svetnik in zaščitnik hrvaškega naroda, za svetnika razglašen leta 1970. Postopek za beatifikacijo Stepinca se je začel leta 1981 in končal leta 1998 (Pacek 2016, 371; Batelja 1999, 210). 
Po dolgotrajnih pogajanjih sta obe strani junija 1966 podpisali protokol, ki pa je vseboval le osnovna izhodišča za urejanje odnosov. Jugoslavija je v njem poudarila svobodo vesti in veroizpovedi, ločitev Cerkve od države, enakopravnost vseh verskih skupnosti in vseh državljanov ne glede na veroizpoved, priznala je jurisdikcijo Svetega sedeža nad Cerkvijo v Jugoslaviji in zagotovila jugoslovanskim škofom pravico do rednih stikov s Svetim sedežem. Sveti sedež je na jugoslovansko zahtevo potrdil načelno stališče, da bo Cerkev delovala znotraj verskih okvirov, strinjal se je, da duhovniki ne smejo zlorabljati vere $v$ politične namene, in obsodil politični terorizem. Pomemben del protokola je bila zaveza k obnovitvi odnosov na ravni poslanikov. Dodatek k protokolu je vseboval izjave o vprašanjih, ki jih obe strani zaradi nesoglasij nista mogli rešiti: delovanje Cerkve na področju vzgoje in izobraževanja, medijev ter dobrodelne dejavnosti, delovanje duhovniških društev, delovanje duhovnikov v emigraciji, vrnitev razlaščenih nepremičnin, želja Jugoslavije, da bi bili novi škofje imenovani z njeno vednostjo (Režek 2002, 320-321; Pacek 2016, 372-374; AJ 837, šk. II-10, Informacija, 27. 5. 1966, 4-5).

\section{Po sprejetju protokola}

Novembra 1966 sta bila na obeh straneh imenovana vladna odposlanca in Jugoslavija je postala prva komunistična država, ki je s Svetim sedežem ponovno vzpostavila diplomatske odnose. Po sprejetju protokola dialog med Jugoslavijo in Svetim sedežem ni bil nikoli več prekinjen, a odnosi so bili daleč od dobrih - celo boljši med Jugoslavijo in Svetim sedežem kot med oblastjo in Cerkvijo v Jugoslaviji. Težave sta obe strani videli v delu duhovščine, predvsem hrvaške. Čeprav Sveti sedež s položajem Cerkve v Jugoslaviji ni bil popolnoma zadovoljen, pa je v sodelovanju videl možnost za utrditev položaja v državah članicah gibanja neuvrščenih in za urejanje odnosov z drugimi komunističnimi državami. Sveti sedež je v Jugoslaviji tako urejal škofijske meje, ustanavljal cerkvene pokrajine ali imenoval nove škofe, medtem ko se v sporna vprašanja med Cerkvijo in državo na lokalnem nivoju ni vpletal, temveč je reševanje težav prepuščal lokalnim škofom (Pacek 2016, 376-379). Mednarodni vpliv sporazuma je viden tudi iz jugoslovanskih dokumentov, kjer je oblast opažala, da je dokument vzbudil veliko zanimanje tako na Zahodu kot na Vzhodu. Razen, skrajno reakcionarnih krogov', kar pomeni emigracijo v Evropi in Združenih državah Amerike, naj bi Zahod sporazum ocenil ugodno - kot uspeh ene in druge strani. Komunistične države naj bi kazale poseben interes za podobno urejanje odnosov s Svetim sedežem, sporazum pa ocenile »kot velik uspeh naše države« (AJ 837, šk. II-10, Stanje odnosa, 9. 10. 1967, 15-16).

Dejansko je oblast do Cerkve po podpisu protokola vodila dvojno politiko. Predvsem na lokalni ravni so verniki še vedno doživljali neenakopravnost in razlikovanje. A cerkveno in versko življenje je vseeno doživljalo razcvet: povečal se je obisk verouka, gradili so se novi bogoslužni objekti, verski tisk je postajal močnejši, poraslo je število duhovnih in redovnih poklicev, povečala se je vloga laikov ter delovanje mladinskih in študentskih skupin (Dolinar 1998, 229-230; Pacek 2018, 
751-762; 2019, 171-177). Kljub trudu za normalizacijo odnosov je oblast pri vzgoji mladine, pa tudi na drugih področjih, v Cerkvi še vedno videla tekmeca.

$\checkmark$ dokumentih je vedno prisotna skrb zaradi širitve dejavnosti Cerkve. Oblast je vedno znova ugotavljala, da je dejavnost Cerkve $v$ državi čedalje bolj raznovrstna in intenzivna. $\mathrm{K}$ temu je, kot je priznala, pripomogel tudi drugi vatikanski koncil s svojo vizijo preporoda in približevanja ljudem. Cerkev naj bi bolj pogumno kot prej uporabljala nove oblike delovanja, poskušala naj bi posodobiti delovanje na vseh področjih in s tem intenzivirati verska čustva ljudi ter okrepiti svoj položaj v socialistični družbi. Oblast je menila, da Cerkev pozorno spremlja, kaj se dogaja v državi, da spremlja in proučuje stališča družbeno-političnih dejavnikov na terenu ter da jo še zlasti na Hrvaškem skrbijo spremembe v odnosih s Svetim sedežem (AJ 837, šk. II-10, Stanje odnosa, 9. 10. 1967, 16-17). Oblast ni bila zadovoljna z izpostavljanjem odprtih vprašanj o svobodi veroizpovedi in opravljanju verskih obredov. Skrbel jo je razvoj pastoralnih dejavnosti med delavci na začasnem delu v tujini (najbolj med Hrvati), razvoj pastoralnega turizma, javno praznovanje cerkvenih praznikov, pa gradnja novih cerkvenih objektov, vključevanje mladine v tečaje, izlete, športne in druge dejavnosti ter porast verskega tiska. Oblast se je bala, da je le še vprašanje časa, kdaj bo Cerkev našla svoj prostor $v$ drugih sredstvih javnega obveščanja. Tudi njena želja po svobodnem opravljanju karitativne dejavnosti pri oblasti ni naletela na odobravanje, saj je socialno skrb za državljane videla kot enega od svojih poglavitnih ciljev (AJ 837, šk. II-10, Stanje odnosa, 9. 10. 1967, 18-25).

Oblast je Cerkvi očitala tudi politično dejavnost, ki pa jo je razumela precej široko. Po njenem je obsegala vprašanja nacionalnih odnosov, vpliva emigracije, izobraževanja mladine, uporabe sredstev javnega obveščanja, karitativne dejavnosti, materialnih težav ter nekaterih ,manj opaženih'vprašanj - dejansko celotno delovanje Cerkve. Pri nacionalnih odnosih naj bi bilo problematično, da se nekateri škofje opredeljujejo kot predstavniki hrvaškega ali slovenskega naroda oziro$\mathrm{ma}$, da so nekatera glasila vero tesno povezovala z nacijo. Oblast se je vedno bala vpliva katoliške emigracije. Hrvaški so očitali, da razvija kult Stepinca kot borca in mučenika za vero, Cerkev in Hrvaško. Vprašljiva je bila tudi finančna pomoč Cerkvi v domovini (AJ 837, šk. II-10, Neka pitanja, 31. 10. 1968, 4-7). Cerkvi so najbolj od vsega očitali ,agresivnost' na področju izobraževanja mladine, saj so se bali, da se bo s tem zmanjšala izobraževalna funkcija šole in države. Zapisali so, da so pogoste pritožbe škofov zoper prosvetne delavce, šole in druge inštitucije, da onemogočajo versko vzgojo in Cerkvi tako očitali propagando proti socialistični ureditvi (AJ 837, šk. II-10, Neka pitanja, 31. 10. 1968, 8-10). Oblast je še menila, da Cerkev kar naprej izvaja pritisk za denacionalizacijo mnogih objektov - pri tem je zanimivo, da so zapisali, da bi podrobnejša analiza pokazala, da je pri nacionalizaciji res prišlo do posameznih pretiravanj, toda možni popravki bi lahko odprli mnoge težave (AJ 837, šk. II-10, Neka pitanja, 31. 10. 1968, 19).

Kljub vsem težavam, ki jih dokumenti izpostavljajo, je oblast vseeno menila, da so se odnosi med državo in Cerkvijo po podpisu protokola nekoliko izboljšali, izpostavili so tudi pozitivno sodelovanje s Svetim sedežem. Zapisali pa so, da si Cer- 
kev protokol razlaga kot možnost za razširitev svojega delovanja, medtem ko je bila oblast mnenja, da je cilj protokola depolitizacija Cerkve (AJ 837, šk. Il-10, Neka pitanja, 31. 10. 1968, 15-18). Zaključki analize odnosov z verskimi skupnostmi so pokazali, da oblast ni videla potrebe po spremembi dotedanje politike in načina komuniciranja z verskimi skupnostmi. Duhovniška društva je še naprej razumela kot koristna za približevanje nižji duhovščini, zato da jim je treba povečati materialno podporo. Zelo si je tudi prizadevala, da bi onemogočila vplive emigracije in verskega izobraževanja na mladino. Menila je, da je potrebna sistemska analiza verskega tiska, da bi lahko omejili njegovo širitev. Kljub temu je veliko vprašanj ostalo ,strokovno neobdelanih': skrajšanje vojaškega roka za bogoslovce, praznovanje cerkvenih praznikov, zdravstveno zavarovanje duhovnikov, vračanje matičnih knjig, vračanje nacionaliziranega premoženja, sprememba predpisov o pravici do splava, svobodno zbiranje prostovoljnih prispevkov in pospešitev postopkov za pridobivanje gradbenih dovoljenj (AJ 837, šk. II-10, Neka pitanja, 31. 10. 1968, 21-25).

Leta 1970 sta Jugoslavija in Sveti sedež obnovila odnose tudi na ravni veleposlaništev (Pacek 2016, 380). Propaganda proti Cerkvi se je nekoliko omilila, a nezaupanje oblasti do nje je na lokalnem nivoju ostajalo. Tako lahko v dokumentih iz istega leta ponovno preberemo, da del duhovščine, zlasti na Hrvaškem, zahteva ,politizacijo' Cerkve (pod čimer je oblast razumela angažiranje Cerkve na vseh področjih družbenega življenja), da zahteva enakopraven odnos v sredstvih javnega obveščanja in posveča večjo pozornost nacionalnemu vprašanju. Katoliška Cerkev naj bi pri svojih dejavnostih ( $v$ nasprotju s pravoslavno, ki naj bi bazo iskala predvsem v podeželskemu prebivalstvu) svoj vpliv širila v vseh slojih prebivalstva. V poskusih obnove svoje dejavnosti naj bi Cerkev po mnenju oblasti tako na Hrvaškem kot v Sloveniji uvajala nove metode dela in različne oblike delovanja, ki niso bile izrazito verske narave (organiziranje izletov, športnih dejavnosti, tečajev, krožkov, amaterskih skupin in podobno). Predvsem pa je vedno znova izpostavljala prizadevanje Cerkve za obnovitev izobraževalne dejavnosti (AJ 837, šk. II-10, Ideološko-politički aspekti, 24. 4. 1970, 6-7).

Obtožbe o ,politizaciji` Cerkve in prizadevanju za širjenje njene dejavnosti so se nadaljevale tudi v naslednjih letih. Radikalizacijo odnosov, do katere je prišlo v sedemdesetih letih, lahko povezujemo z vrnitvijo k stari partijski liniji (Dolinar $1998,229)$. ,Politizacija' Cerkve je po mnenju oblasti začela vplivati tudi na odnose med Jugoslavijo in Svetim sedežem - posledično se je poslabšal ugled Jugoslavije v mednarodnem prostoru. Zato je oblast menila, da je pri teh vprašanjih potreben večji napor zveze komunistov in drugih družbeno-političnih organizacij. Menila je tudi, da je treba v strokovni literaturi, medijih in javnosti nasploh sprožati vprašanja nadaljnjega razvoja socialističnega šolstva, hkrati pa spremljati družbeno-politično primernost prosvetnih delavcev in drugih javnih uslužbencev (AJ 837, šk. II-10, Informacija, 3. 12. 1973, 1-3). Boj za ,nevtralno' šolo je bila glavna skrb oblasti, saj se je bala, da bi oživljena dejavnost Cerkve na tem področju slabo vplivala na zaupanje $v$ socialistično samoupravno ureditev in razbijala enotnost jugoslovanskih narodov (AJ 837, šk. II-10, Informacija, 22. 11. 1973, 2-3). Oblast 
je rada natančno preiskovala poslovanje posameznih verskih karitativnih organizacij in tiska. Tako so se leta 1974 pod drobnogledom znašli Družina in Ognjišče ter mednarodni sklad Gladno dete iz Zagreba - očitali so jim nepravilnosti v poslovanju z devizami in pri zbiranju prostovoljnih prispevkov. Časopisoma so očitali še ,bujenje klerikalizma' in načrtovali pregled drugih verskih časopisov (AJ 837, šk. II-10, Informacija, 19. 11. 1974, 1-2).

Odnos do Cerkve se je počasi začel spreminjati šele sredi osemdesetih let, na kar je vplivalo več dejavnikov: notranjepolitične razmere v Jugoslaviji in Sloveniji, kadrovske spremembe $v$ slovenskem cerkvenem vrhu in politika papeža Janeza Pavla II. Kmalu so se pokazale tudi spremembe v vrednotenju religioznosti, ustavil se je proces sekularizacije. (Toš 2011, 138-139; Rus in Toš 2005, 181-182). A oblast je delovanje Cerkve še vedno spremljala in se bala njene dejavnosti. ${ }^{29} \mathrm{Kljub}$ temu so bila posamezna odprta vprašanja (praznovanje božiča, opravljanje karitativne dejavnosti, verska oskrba $v$ zaporih in domovih za ostarele) postopoma rešena do konca desetletja, nekatera pa šele po razpadu Jugoslavije.

\section{Zaključek}

Ves obravnavani čas je oblast poskušala med jugoslovansko duhovščino povzročiti razkol. Iz pregledanih dokumentov je vidno, da je oblast dosti večjo pozornost namenjala duhovnikom in razmeram na Hrvaškem, medtem ko je $v$ slovenskih duhovnikih videla večinoma zmerno linijo - čeprav jo je skrbelo tudi njihovo delo. Pri tem je treba omeniti, da je bila republiška oblast v Sloveniji veliko bolj omejevalna kot drugod. V Sloveniji je bila tako uvedena dosledna ločitev Cerkve in države, ukinjene so bile verske šole, prepovedana je bila tudi karitativna dejavnost. $\mathrm{Na}$ Hrvaškem do popolne ukinitve verskih šol ali prepovedi opravljanja karitativne dejavnosti ni prišlo, del duhovščine se je tudi precej izraziteje upiral. Prav zato je zvezna oblast največjo težavo videla tako v hrvaški duhovščini kot emigraciji - in jo je v svojih dokumentih tudi najbolj izpostavljala.

Od začetnega zaostrovanja zaradi ideološko-političnih razlogov se je skrb oblasti od šestdesetih let naprej postopoma usmerila na delovanje Cerkve na vseh področjih družbenega življenja. Oblast je skušala omejiti zlasti njeno dejavnost na področju dela z mladimi, pa tudi izdajanje verskega tiska in opravljanje karitativne dejavnosti. Hkrati jo je skrbelo širjenje njenega vpliva na vse družbene sloje. V sedemdesetih letih se je odnos oblasti do Cerkve ponovno poslabšal, kar je bila posledica sprememb na notranjepolitičnem področju.

Za razumevanje zapletenih, pogosto napetih odnosov med državo in Cerkvijo je nujno potrebno poznavanje domačih in drugih arhivskih arhivov. Gradivo Arhiva Jugoslavije je sicer zelo zanimivo, a predstavlja specifičen pogled najvišjih dr-

29 Priročnik za delo milice iz leta 1985 Cerkev še vedno opredeljuje kot enega od glavnih notranjih sovražnikov, zato je bil predviden lokalni nadzor tako nad duhovščino kot tudi nad vidnejšimi laiki (Griesser Pečar 2013, 353). 
žavnih organov. Najpogosteje je gradivo v obliki poročil, zato lahko celoten razvoj odnosov med državo in Cerkvijo predstavi le deloma. Njegov pomen je v tem, da predstavlja uradno stališče oblasti glede odnosov med Jugoslavijo in Svetim sedežem, pa tudi s stališča ob primerjavi dogajanja v posameznih republikah.

\section{Kratica}

AJ - Arhiv Jugoslavije.

\section{Reference}

\section{Arhivska vira}

AJ 144 - Arhiv Jugoslavije, Savezna komisija za verska pitanja, fasc. 5, 6, 19, 23.

AJ 837 - Arhiv Jugoslavije, Kabinet pretsednika republike, šk. II-10.

\section{Druge reference}

Batelja, Juraj. 1999. Beatifikacija kardinala Alojzija Stepinca: Događaj - poruka i poticaj za sadašnje i buduče naraštaje. Bogoslovska smotra 69, št. 2/3:209-232.

Čepič, Zdenko. 2005. Agrarna reforma in kolonizacija. V: Jasna Fischer, ur. Slovenska novejša zgodovina: Od programa Zedinjena Slovenija do mednarodnega priznanja Republike Slovenije, 1848-1992. Zv. 2, 883-889. Ljubljana: Inštitut za novejšo zgodovino.

Dolinar, France M. 1998. Katoliška Cerkev v Sloveniji po drugi svetovni vojni. V: Drago Jančar, ur. Temna stran meseca: kratka zgodovina totalitarizma v Sloveniji, 222-233. Ljubljana: Nova revija.

Gabrič, Aleš. 2016. Boj proti katoliškemu tisku. V: Bogdan Kolar, ur. Acta Ecclesiastica Sloveniae, št. 38, Miscellanea, 307-323. Ljubljana: Teološka fakulteta.

- - - 2003. Izključevanje Teološke fakultete iz Univerze v Ljubljani. Bogoslovni vestnik 63, št. 2:255-280.

- - . 2009. Sledi šolskega razvoja na Slovenskem. Ljubljana: Pedagoški inštitut.

Griesser Pečar, Tamara. 2005. Cerkev na zatožni klopi: Sodni procesi, administrativne kazni, posegi, ljudske oblasti'v Sloveniji od 1943 do 1960. Ljubljana: Družina.

- - - 2017. Cirilmetodijsko društvo katoliških duhovnikov LRS in ,ljudska oblast' med najhujšo represijo. Bogoslovni vestnik 77, št. 2: 423437.
- - -. 2012. Katoliška cerkev v komunistični Sloveniji: ,Sovražnik številka ena'. V: Mateja Čoh Kladnik in Neža Strajnar, ur. Represivne metode totalitarnih režimov: Zbornik prispevkov z mednarodnega znanstvenega posveta, 131145. Ljubljana: Študijski center za narodno spravo.

- - - 2013. Katoliška cerkev v arhivu slovenske tajne policije. V: Damjan Hančič, Gregor Jenuš in Neža Strajnar, ur. Odstiranje zamolčanega: zbornik prispevkov, 351-362. Ljubljana: Študijski center za narodno spravo.

Kurnjek, Branko, Marjan Maučec in Iztok Mozetič. 1999. Dnevno časopisje o duhovniških procesih na Slovenskem 1945-1953. Ljubljana: Inštitut za zgodovino Cerkve pri Teološki fakulteti.

Mikola, Milko. 2003. Religija, Cerkev in šola v dokumentih občinskih komitejev ZKS Zgodovinskega arhiva Celje. Celje: samozaložba.

Pacek, Dejan. 2016. Nekateri bistveni vidiki odnosa med Svetim sedežem in Jugoslavijo v obdobju 1953-1970. V: Bogdan Kolar, ur. Acta Ecclesiastica Sloveniae, št. 38, Miscellanea, 361383. Ljubljana: Teološka fakulteta.

- - - 2018. Odziv oblasti na pastoralno dejavnost katoliške Cerkve v Sloveniji v letih 1965-1975 (1. del). Bogoslovni vestnik 78, št. 3:745-766.

- - - 2019. Odziv oblasti na pastoralno dejavnost katoliške Cerkve v Sloveniji v letih 1965-1975 (2. del). Bogoslovni vestnik 79, št. 1:153-179.

Režek, Mateja. 1999. „Vprašanje svobode vere je vprašanje osvoboditve cerkve od Vatikana«: Odnosi med državo in katoliško cerkvijo v letih 1949-1953. Zgodovinski časopis 53, št. 3: 367-390.

- - . 2002. Država in Katoliška cerkev v Jugoslaviji (1945-1966). V: Alenka Šelih in Janko Pleterski, ur. Država in cerkev: Izbrani zgodovinski in pravni vidiki, 309-321. Ljubljana: Slovenska akademija znanosti in umetnosti. 
- - - 2005. Zaostritev politike do Rimskokatoliške cerkve. V: Jasna Fischer, ur. Slovenska novejša zgodovina: Od programa Zedinjena Slovenija do mednarodnega priznanja Republike Slovenije, 1848-1992, zv. 2, 952-956. Ljubljana: Inštitut za novejšo zgodovino.

Rus, Veljko, in Niko Toš. 2005. Vrednote Slovencev in Evropejcev: Analiza vrednotnih orientacij Slovencev ob koncu stoletja. Ljubljana: Fakulteta za družbene vede.

Ščavničar, Darko. 2012. Odvzem cerkvenega premoženja z agrarno reformo po letu 1945 na primeru župnij Dobrovnik, Lendava in Bogojina. V: Mateja Čoh Kladnik in Neža Strajnar, ur. Represivne metode totalitarnih režimov: Zbornik prispevkov z mednarodnega znanstvenega posveta, 146-163. Ljubljana: Študijski center za narodno spravo.
Toš, Niko. 2011. Longitudinalni projekt slovenskega empiričnega družboslovja: SJM 1966-2010. V: Niko Toš in Karl H. Müller, ur. Primerjalno družboslovje: Metodološki in vsebinski vidiki, 119-160. Ljubljana: Fakulteta za družbene vede. 